\title{
Development of a furrow irrigation method
}

\author{
Alexander Apalkov ${ }^{1}$, Sergey Apalkov ${ }^{2}$, Sergey Kuren ${ }^{1}$, Sergey Popov ${ }^{1, *}$, and Julianna \\ Marchenko ${ }^{1}$ \\ ${ }^{1}$ Don State Technical University, 1, Gagarin sq., 344003, Rostov-on-Don, Russia \\ ${ }^{2}$ Don State Agrarian University, 111, Pushkinskaya st., 346428, Novocherkassk, Russia
}

\begin{abstract}
The article describes the technology of laying a film covering with a specially selected perforation of holes on the laid groove with fastening the edges of the covering along its entire length. Calculations of the irrigation rate are given, which must be strictly observed for economical water use when irrigating along furrows. The use of a perforated polyethylene film screen will provide the required moisture capacity throughout the season. Stabilization of the irrigation regime will ensure high yields while complying with the requirements of the law on environmental protection. The most effective agrotechnical conditions are proposed and recommendations for the growing season are given.
\end{abstract}

\section{Introduction}

When irrigating crops, large losses of irrigation water are observed, which leads to negative consequences in the area of irrigated agriculture. In modern conditions, surface irrigation methods are again gaining great importance, and especially furrow irrigation, which is the most affordable and does not require energy costs. However, one of the main disadvantages of this irrigation method is large loss of water for filtration and evaporation. These are not only economic losses, but also emerging environmental problems from the larger involvement of agricultural chemistry, which causes irreparable damage to nature and health of the population.

The main objective of this work is to develop a method for furrow irrigation of agricultural crops on heavy soils with low irrigation rates [1-12].

\section{Theoretical part}

Furrow irrigation, due to its simplicity, has advantages over other surface irrigation methods. The soils that make up the channel of the furrows change their permeability under the influence of compaction, colmatation, precipitation and other reasons. At the same time, the change in water permeability towards its decrease occurs the sharper, the longer the furrows are exploited and the higher the initial water permeability of soils was. Therefore, the conditions of absorption from irrigation furrows differ from the design schemes used as the basis for theoretical studies. In addition, composition of soils composing channels of

\footnotetext{
*Corresponding author: spopov1957@yandex.ru
} 
furrows is usually heterogeneous in its properties along the entire length of furrow. Such heterogeneity in a number of cases causes not continuous, but streaky or vein movement of water in the soil. In addition, in the process of operation, there is a heterogeneity of the water-physical properties of soils, which is determined not only by the spatial and depth differences in their composition, but also by the changes that occur under the influence of water over a long period of furrow operation (siltation, clogging, compaction, alluvial , structuring of the furrow bed, etc.).

The existing methods do not allow to ensure good quality of irrigation and high labor productivity when irrigating crops with a shallow root system on poorly water-permeable soils with the required irrigation rate of $250-400 \mathrm{~m} 3 / \mathrm{ha}$. The analytical review also showed that the issues of furrow irrigation on heavy soils for crops with an irrigation rate of 300$400 \mathrm{~m} 3 /$ ha have not been studied with a length of 200-300 $\mathrm{m}$.

The expediency of using a perforated film coating for irrigation furrows is beyond doubt, since it leads to a significant increase in yield. The essence of the method of irrigation along furrows and the technology of a mechanized device of irrigation furrows using a unit with a combined working body consists in laying a film coating with specially selected perforation of holes on a previously made furrow with fixing the edges of the coating along the entire length of the furrow. The schemes of furrows with film coatings are shown in Figure 1.

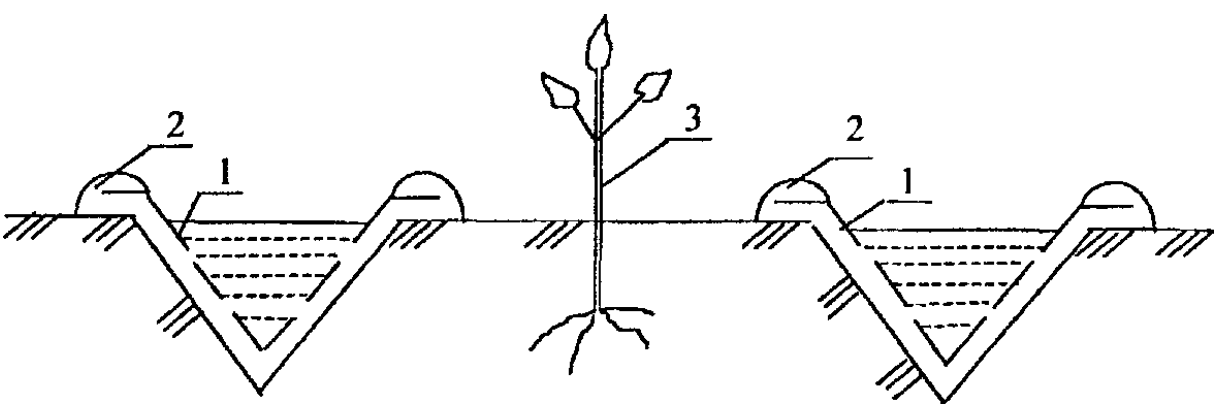

Fig. 1. Scheme of grooves with perforated film coating 1 - perforated film coating; 2 - dusting edges of the film; 3 - plants grown in the aisle.

When determining the throughput of a furrow, hydraulic calculations are made according to generally accepted methods, taking into account the absorption process and water consumption. The proposed method for determining the main elements of the furrow irrigation technique makes it possible to calculate the hydraulic characteristics of flow in the furrow - speed, depth, flow rate, as well as volume of water supplied, duration of water supply and length of the furrow.

The main advantages of the new irrigation method are:

- reduction of water consumption for irrigation of agricultural crops (up to 30\%);

- creation of favorable conditions for the development of plants by retaining moisture in the root layer;

- protection of plants from spring frosts, creation of optimal thermal conditions;

- reduction of water losses for evaporation from surface of the furrow and for deep infiltration due to uniform redistribution of seeping water through holes in the film coating; - reduction of furrow roughness to values $p=0,025-0,030$ (against $p-0,04-0,05$ for irrigation furrows without coating);

- decrease in the number of crops irrigated during the irrigation season;

- reducing the degree of overgrowth of furrows with weeds;

- prevention of groundwater level rise. 
In order to increase the productivity of work on the creation of irrigation furrows with a film coating, a technology has been developed for their mechanized device using a combined-type unit. The unit developed by us makes it possible to cut irrigated furrows with simultaneous decompaction of lumpy formations in the process of cutting them, followed by laying a perforated plastic film and rolling along the perimeter of the furrow.

Laying of a film panel with a width of $0.7-1.0 \mathrm{~m}$ and a length of $50 \mathrm{~m}$ is carried out directly on the surface of the furrow in sections with an overlap. Securing the edges of the film coating can be done by sprinkling them with soil or by pinning them with metal pins every $3-5 \mathrm{~m}$ if the wind speed is more than $10 \mathrm{~m} / \mathrm{s}$.

At the end of the irrigation season, the panels are rolled up for ease of transportation.

\section{Calculation of water consumption for furrow irrigation}

The purpose of this study is to develop agrotechnical measures to maintain constant soil moisture throughout the growing season with economical consumption of irrigation water. [13-20].

Irrigation rate - (or irrigation rate) is the amount of water of a certain quality that must be supplied for the entire irrigation period per hectare of irrigated area in addition to its natural reserves in the soil in order to obtain the planned yield in specific climatic conditions.

The irrigation rate is usually determined by the formula:

$$
J_{\mathrm{n}, \mathrm{nt}}=d_{w m}+V_{e t},
$$

where $J_{n, n t}-$ net irrigation rate, $\mathrm{m} 3 / \mathrm{ha}$;

$d_{w m}$ - moisture deficit in the water balance, $\mathrm{mm}$;

$V_{e t}$ - technical water losses in the irrigated field as a result of infiltration below the calculated layer, water discharge outside the field, evaporation during irrigation.

The moisture deficit in the water balance $(\mathrm{mm})$ is calculated according to the dependence

$$
d_{\mathrm{wm}}=E T_{\text {crop }}-p_{e}-\left(V_{s t}-V_{\text {end }}\right)-V_{q \cdot d s},
$$

where $E T_{\text {crop }}$ - total water consumption of the crop for the settlement period, $\mathrm{m} 3 / \mathrm{ha}$; $p_{e}$ - effective atmospheric precipitation for the estimated period of a given provision, $\mathrm{m} 3 / \mathrm{ha}$;

$V_{s t}, V_{\text {end }}$ - respectively, the moisture reserve at the beginning and end of the growing season, m3/ha;

$V_{q_{\cdot d s}}$ - the volume of water used by plants from groundwater, $\mathrm{m} 3 /$ ha.

Thus, the irrigation rate, where all elements of the water balance are taken into account, can be written in the form

$$
d_{\mathrm{wm}}=E T_{\text {crop }}-p_{e}-\left(V_{s t}-V_{\text {end }}\right)-V_{q \cdot d s}+V_{\mathrm{et}} .
$$

Therefore, to calculate the value of the irrigation (net) rate, it is necessary to know the moisture reserve at the beginning and end of the growing season $(\mathrm{m} 3 / \mathrm{ha})$, useful rainfall $(\mathrm{m} 3 / \mathrm{ha})$, recharge groundwater and determine the value of the total water consumption of crops (m3/ha), ET $T_{\text {crop }}$.

The total water consumption is determined by many methods. Let's consider the main ones.

I. Water balance method (m3/ha) 


$$
E T_{\text {crop }}=p_{e}+\left(V_{s t}-V_{\text {end }}\right)+V_{q \cdot d s}+J_{\mathrm{n}, \mathrm{nt}}, 8,5
$$

II. Heat balance method. The radiation balance is determined

$$
R=\mathrm{LET}_{\text {crop }}+B+T,
$$

where $R$ - radiation balance, $\mathrm{kcal} / \mathrm{ha}$;

$L$ - latent heat of vaporization, $\mathrm{m} 3$;

$B$ - the amount of heat used to heat the soil, $\mathrm{J} / \mathrm{ha}, \mathrm{kcal} / \mathrm{ha}$;

$T$ - turbulent heat flux, $\mathrm{J} / \mathrm{ha}, \mathrm{kcal} / \mathrm{ha}$.

$$
\mathrm{ET}_{\text {crop }}=\frac{1}{L}(R-B-T) .
$$

III.

Semi-empirical methods (experimental)

1. Method I.A. Sharova. The total water consumption is determined by the following relationship (m3/ha)

$$
\mathrm{ET}_{\text {crop }}=e \sum t
$$

where e - evaporation module per 1 degree of heat, $\mathrm{m} 3$ / gr.;

$\sum t$ - the sum of the average daily air temperatures for the growing season, ${ }^{\circ} \mathrm{C}$.

2. Method A.M. Alpatieva

$$
E T_{\text {crop }}=C \sum d
$$

where $C$ - biological curve coefficient, calculated;

$\sum d$ - the sum of the average daily deficits in air humidity for the billing period, $\mathrm{mm}$.

3. Method A.N. Kostyakov based on the knowledge of the water consumption coefficient

$$
E T_{\text {crop }}=C_{m} \cdot Y \text {, }
$$

where $C_{m}$ - water consumption coefficient, $\mathrm{m} 3 / \mathrm{ha}$;

$Y$ - planned yield of the main product, $\mathrm{t} / \mathrm{ha}$.

In our conditions, the total water consumption will be determined by the formula of A.N. Kostyakov. If the moisture reserves at the beginning and end of the growing season are unknown, then the value of the irrigation rate can be determined by the dependence:

$$
J_{\mathrm{n}, \mathrm{nt}}=E T_{\text {crop }}-\mu_{1} p_{1}-\mu_{2} p_{2}-\mu_{3} p_{3}-V_{q . d s},
$$

where $\mu_{1} \mathrm{p}_{1} ; \mu_{2} \mathrm{p}_{2} ; \mu_{3} \mathrm{p}_{3}$ - useful precipitation of a given provision for the growing, nongrowing heat and non-growing cold periods, $\mathrm{m} 3 /$ ha.

To develop irrigation along flow furrows, it is necessary to carry out the following calculations. The elements of irrigation technique includecя: Dir - irrigation rate, m3/ha; i longitudinal slope; If - irrigation furrow length, $\mathrm{m}$; qf - furrow rate, $\mathrm{m} 3 / \mathrm{s} ; \mathrm{t}$ - travel time, hour; Ko - absorption rate, $\mathrm{m} / \mathrm{h}$; a - coefficient taking into account the attenuation of the absorption rate. Having these parameters and using the formulas of hydraulics for the steady process of water movement, it is possible to determine the furrow flow (qf), furrow length (lf), duration of feeding into the furrow ( $\mathrm{t}$ ).

In accordance with the proposed calculation, by setting the irrigation rate (Dir), one can find the furrow length, water volume absorbed by the soil, and irrigation time.

To determine the length of the furrow, you can use the formula

$$
l_{f}=\frac{10000 \cdot q_{f} \cdot t}{\operatorname{Dir} \cdot a}
$$


where $q_{f}$ - furrow rate, $\mathrm{m} 3 / \mathrm{s}$;

$t$-duration of water supply to the furrow, $\mathrm{s}$.

Determine the volume of water supplied to the furrow during irrigation without discharge, taking into account the volume of water that is absorbed by soil:

$$
V_{1}=\frac{\text { Dir } \cdot a \cdot l_{f}}{10000}=w_{a v} \cdot \beta \cdot t,
$$

where $w_{a v}$ - average absorption rate, $\mathrm{m} / \mathrm{h}$;

$\beta$ - active wetted perimeter.

$\beta=v \cdot d_{f} \sqrt{1+m^{2}}$,

where $v$-coefficient taking into account lateral absorption of the soil into the slopes of the furrow by capillary path (is taken depending on the composition of the soil: for heavy soils $v=2,5$; average $-2,0$; light $-1,5)$.

$$
V_{1}=w_{a v} \cdot \beta \cdot t^{1-a} .
$$

The time during which water continues to flow into the furrow is determined by the formula:

$$
t=\left(\frac{D i r \cdot a}{10000 \cdot w_{o} \cdot \beta}\right)^{1 / 1-a}
$$

\section{Results and discussion}

The above method for determining the parameters of furrow irrigation is in good agreement with the processing of the results obtained in the study in natural conditions. When irrigating along flow furrows, soil moisture along the furrow length is uneven, which leads to negative consequences [21-28].

To ensure constant moisture content during the period of plant development, the following agrotechnical conditions must be met:

- constantly maintain in the soil moisture that is optimal for the growth and development of plants, which contributes to the preservation of the structure, water-physical properties and soil fertility;

- during surface irrigation, prevent the process of puddling, surface runoff and water erosion of the soil;

- prevent waterlogging of the soil, excluding cases of water discharge outside the aeration zone, which is the reason for the replenishment and rise of groundwater, and, as a rule, salinization and waterlogging of lands.

To fulfill these agrotechnical requirements, it is necessary to strictly observe the calculated irrigation norms, depending on humidity, throughout the growing season. To maintain moisture content in the active soil layer, it is necessary to control it systematically every 5-10 days and carry out the next vegetative irrigation when the moisture content drops to $0.6-0.8$ of the lowest moisture capacity.

The new method of furrow irrigation using a perforated film coating allows to reduce water losses due to non-productive filtration up to $20 \%$ and evaporation - up to $30 \%$. At the same time, more favorable conditions are created for the development of plants due to an increase in the duration of moistening of the root-inhabited soil layer and the degree of overgrowing of rows with weeds decreases.

The results of field studies showed that 2-3 days after watering in the aisle in the case of a film coating, soil moisture in the root layer increases by $40-70 \%$ due to a decrease in evaporation from the soil surface. Reduction of losses for filtration with a perforated film 
coating at the absorption stage is $12 \%$, and at the stage of steady filtration by $20 \%$. It has been established that the absorption process in a furrow with a perforated film coating takes 5-10 minutes. [29-31].

Studies of the contours of soil wetting have established the optimal inter-furrow distance of overlapping adjacent contours for light clay soils of $0.7 \mathrm{~m}$. Three zones have been identified in the moisture contour: complete, incomplete moisture saturation and capillary distribution of moisture.

\section{Conclusions}

1. For economical use of water when irrigating along furrows, it is necessary to strictly observe the calculated irrigation rate.

2. Due to the use of a perforated polyethylene film screen, the required moisture capacity is provided throughout the season.

3. The experimentally established dependences of filtration losses convincingly indicate a high effect of soil water retention for a perforated film coating.

4. If the entire complex of the specified agrotechnical requirements is observed, it is possible to ensure high yields.

\section{References}

1. M. N. Moskovsky, A. V. Kovaleva, S. G. Kuren, ARPN Journal of Engineering and Applied Sciences, 12(22), 6414 (2017)

2. V. V. Ivanov, N. P. Pogorelov, N. S. Dontsov, Y. N. Denisenko, AIP Conference Proceedings, 2188, 020005 (2019) doi.org/10.1063/1.5138379

3. A. A. Korotky, E. V. Marchenko, S. I. Popov, Ju. V. Marchenko, N. S. Dontsov, E3S Web of Conferences, 175, 05018 (2020) doi.org/10.1051/e3sconf/202017505018

4. V. V. Ivanov, S. I. Popov, N. S. Dontsov, G. E. Ekinil, Ju. A. Oleynikova, Ju. N. Denisenko, E3S Web of Conferences, 175, $05023 \quad$ (2020) doi.org/10.1051/e3sconf/202017505023

5. A. F. Apalkov, S. A. Apalkov, S. G. Kuren, S. I. Popov, N. S. Dontsov, E3S Web of Conferences, 175, 09005 (2020) doi.org/10.1051/e3sconf/202017509005

6. A. A. Korotky, S. I. Popov, G. A. Galchenko, Ju. V. Marchenko, D. S. Drozdov, E3S Web of Conferences, 175, 13019 (2020) doi.org/10.1051/e3sconf/202017513019

7. O. V. Beluzhenko, S. G. Kuren, S. I. Popov, N. S. Dontsov, E3S Web of Conferences, 175, 15017 (2020) doi.org/10.1051/e3sconf/202017515017

8. V. V. Ivanov, S. I. Popov, E. M. Selemeneva, N. T. Babazhanov, AIP Conference Proceedings, 2188, 020015 (2019) doi.org/10.1063/1.5138389

9. V. V. Ivanov, S. I. Popov, Ju. V. Marchenko, E. V. Marchenko, N. S. Dontsov, S. A. Timofeev, IOP Conference Series: Earth and Environmental Science, 403, 012115 (2019) doi:10.1088/1755-1315/403/1/012115

10. A. A. Korotky, E. V. Marchenko, V. V. Ivanov, S. I. Popov, Ju. V. Marchenko, N. S. Dontsov, IOP Conference Series: Earth and Environmental Science, 403, 012116 (2019) doi:10.1088/1755-1315/403/1/012116

11. A. A. Kotesova, S. V. Teplyakova, S. I. Popov, F. C. Kopylov, IOP Conference Series: Materials Science and Engineering, 698, 066029 (2019) doi:10.1088/1757899X/698/6/066029 
12. N. N. Nikolaev, Yu. V. Marchenko, S. K. Filatov, IOP Conference Series: Materials Science and Engineering, 698, 066027 (2019) doi:10.1088/1757-899X/698/6/066027

13. V. Ilyasov, B. Meshi, D. Pham, C. Nguyen, O. Holodova, T. Zhdanova, I. Ershov, N. Prutsakova, I. Popova, Springer Proceedings in Physics, 207, 127-144 (2018) doi:10.1007/978-3-319-78919-4

14. A. Altybayev, A. Zhanbyrbayev, B. Meskhi, D. Rudoy, A. Olshevskaya, A. Prohorova, E3S Web of Conferences, 135, 01078 (2019) https://doi.org/10.1051/e3sconf/201913501078.

15. B. Meskhi, B. Golev, V. Efros, D. Rudoy, A. Olshevskaya, V. Zhurba, Y. Chayka, E3S Web of Conferences, 135, 01083 (2019) https://doi.org/10.1051/e3sconf/201913501083

16. A. A. Kostoglotov, D. S. Andrashitov, A. S. Kornev, S. V. Lazarenko, Measurement Techniques, 62, 497 DOI: 10.1007/s11018-019-01652-8

17. S. V. Lazarenko, A. A. Kostoglotov, Journal of Communications Technology and Electronics, 62(2), 123-127 (2017) DOI: 10.1134/S1064226917020061

18. A. A. Kostoglotov, I. V. Pugachev, A. A. Yachmenov, S. V. Lazarenko, Advances in Intelligent Systems and Computing, 874, 116-124 (2019) DOI: 10.1007/978-3-03001818-4_12.

19. S. V. Lazarenko, A. A. Kostoglotov, A. I. Kostoglotov, Journal of Communications Technology and Electronics, 54(4), 431-438 (2009) DOI: 10.1134/S1064226909040081.

20. S. I. Kambulov, I. V. Bozhko, A. V. Olshevskaya, MATEC Web of Conferences, 224, 05022 (2018) https://doi.org/10.1051/matecconf/201822405022

21. J. Gerber, A. Zavaly, A. Gavrilov, A. Olshevskaya, N. Kiyan, IOP Conf. Series: Earth and Environmental Science, 403, 012014 (2019) doi:10.1088/1755-1315/403/1/012014

22. G. Parkhomenko, S. Kambulov, A. Olshevskaya, A. Babadzhanyan, N. Gucheva, I. Mekhantseva, IOP Conf. Series: Earth and Environmental Science, 403, 012144 (2019) doi:10.1088/1755-1315/403/1/012144

23. N. N. Yazvinskaya, N. E. Galushkin, D. N. Galushkin, B. Yu. Kalmykov, International Journal of Electrochemical Science, 15(1), 412-423 (2020)

24. B. Yu. Kalmykov, S. G. Stradanchenko, A. Y. Sirotkin, A. S. Garmider, Y. B. Kalmykova, ARPN Journal of Engineering and Applied Sciences, 11(17), 1020510208 (2016)

25. I. Y. Visotski, N. A. Ovchinnikov, I. M. Petriashvili, Y. B. Kalmikova, B. Yu. Kalmykov, ARPN Journal of Engineering and Applied Sciences, 10(12), 5150-5156 (2015)

26. B. Yu. Kalmykov, N. A. Ovchnnikov, O. M. Kalmikova, I. K. Guguyev, I. V. Kushnariva, ARPN Journal of Engineering and Applied Sciences, 10(10), 4366-4371 (2015)

27. N. A. Ovchinnikov, B. Yu. Kalmykov, S. G. Stradanchenko, E. A. Kozyreva, O. V. Chefranova, ARPN Journal of Engineering and Applied Sciences, 10(22), 10511$10522(2015)$

28. B. Yu. Kalmykov, N. A. Ovchinnikov, O. M. Kalmikova, V. I. Jigulskii, Y. G. Yurshin, ARPN Journal of Engineering and Applied Sciences, 10(8), 3793-3797 (2015)

29. E. Zubrilina, I. Markvo, V. Novikov, A. Beskopylny, L. Vysochkina, D. Rudoy, A. Butovchenko, IOP Conf. Series: Earth and Environmental Science, 403, 012063 (2019) doi:10.1088/1755-1315/403/1/012063 
30. A. Zavaliy, S. Volozhaninov, O. Shiian, D. Rudoy, A. Olshevskaya, E3S Web of Conferences, 175, $05003 \quad$ (2020) INTERAGROMASH 2020 https://doi.org/10.1051/e3sconf/202017505003

31. Y. Lachuga, A. Soloviev, A. Matrosov, I. Panfilov, V. Pakhomov, D. Rudoy, IOP Conf. Series: Earth and Environmental Science, 403, 012055 (2019) IOP Publishing doi:10.1088/1755-1315/403/1/012055 